\title{
ACCOUNT OF AN EPIDEMIC OF INFLUENZA AMONG AMERICAN TROOPS IN ENGLAND. 1
}

By F. M. MEAder, M.D., Masor, M.C., U.S.A.,

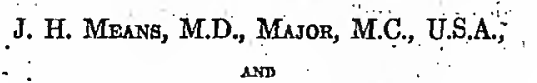

J. G. Hopkins, M.D., CAìtuin, M.C., U.S.A.

(From the Office of the Surgen, Base Section 3, A. E. F.)

INTRODUCTION. The great autumn pandemic of influenza made its first appearance in England with the arrival at the port of Southampton of "Transport 56" from the United States. Following this, nearly every transport that arrived in England for the nest four weeks brought large numbers of men either ill: with the disease or who subsequently developed it. In addition a considerable number of cases broke out among American troops permanently stationed in England. Those who were most affected were the personnel of hospitals that had received patients.

Altogether, from September 20, 1918, when the above-mentioned transport arrived until the present writing, November 14, 1918, there have been approximately 7800 cases of influenza among American troops hospitalized in Great Britain. Of these, about 5000 have been cared for in American and the balance in British hospitals. Of this total number of cases 3350 developed at sea and occurred among a total of approximately 177,000 troops landed in that period. The morbidity and mortality from influenza among troops landing in England is shown in Table I.

TABLE I.- - SHOWING CASES OF INFLUENZA AND DEATHS AT SFA THEREFROM AMONG AMERICAN TROOPS ARRTVING IN ENGLAND.

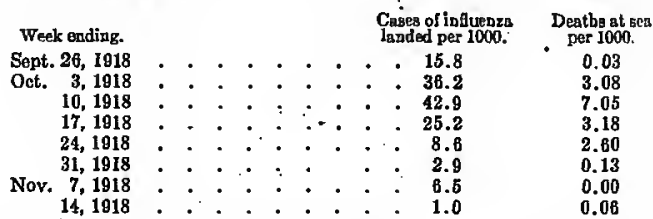

1 The authors of this paper have all been actively ongaged in eomo phase of handling the influenza epidemic in England, and this paper represente in part e report of their own work. In addition, they have acted in an editorial capecity end consolidated the observations made in all the American hospitals. Their sincere thanks are due to the commanding offieers a ad professional staffs of the seversl hospitals for their hearty coōperation. Further, an expression of eppreciation is in order for the intelligent wey thet the cases have been handled and etudied in all the Amerioen hospitals in England. It is hoped. thnt further pepers will eppear, giving, in greater detail, the experience of various clinies. 
In other words, of 177,000 troops landed in the period September 20 to November $14 ; 1918,19$ per thousand were ill with infuenza on arrival and 394, or 2.2 per thousand, died en route. The above table also indicates that the importation of influenza had ceased at the present writing. In addition to the imported cases a certain number developed among a fixed American military population of about 28,000 . Subtracting those that were ill on arrival from the ${ }^{\cdots \cdots}{ }^{*}$ total we have 4450 developing in England among a combined permanent and transient military population of 205,000 . This makes the observed morbidity of influenza 10 per thousand per month for the period September 20 to November 14 , 1918. The actual morbidity is undoubtedly higher, for cases probably developed in the transient troops during the period but after their departure from England. Of these latter cases the writers have no information. There was a total of 900 deaths in England during the period, or a mortality of 2 per thousand per month. Of the total cases of influenza, both on land and sea, 16.5 per cent. died during the period.

The influenzal process was frequently complicated by bronchopneumonia, and this complication, except in rare instances, was the cause of death. Of the total cases of influenza hospitalized, about 2300 , or 29.5 per cent., developed pneumonia, and of these 900 , or 39 per cent., died. When the cases dying at sea are included the percentage of pncumonia cases dying becomes 60 per cent. Assuming the average length of voyage to, be about two weeks, it will be seen that the mortality at sea is about double that on land.

There has not been sufficient clerical force available to show the admission to hospitals of cases of influenza by weeks, but Chart I, which shows the total of cases of pneumonia hospitalized in England by weeks and the deaths therefrom, will give a good idea of the progress and severity of the epidemic. (See Chart I.)

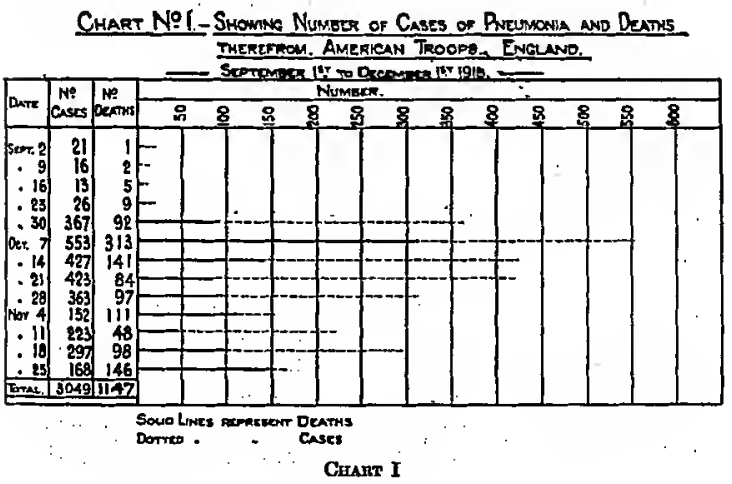


EPIDemolocr. It has not been possible to make detailed statistical studies of all the individual ship epidemics nor of the incidence among permanent personnel as a whole. Such studies, however, have been made in a few instances, and will, by way of illustration, give an excellent idea of the various aspects of the outbreak.

Epmenic of "Transpors 56." This epidemic, which is one of the most severe of the group, has been studied in great detail, and since it can be followed from start to finish, forms an excellent illustration.

The transport left an American port on September 14 with 5951 troops on board. Wben two days from port a medical inspection of the entire personnel showed 7 cases of measles, 1 of which developed bronchopneumonia and died on September 21. During the voyage there developed 14 cases of mumps, 16 of measles, 4 of scarlet fever, 3 of pneumonia and a number of cases of acute respiratory tract infection (influenza). The latter rapidly assumed epidemic proportions, as will be seen in Chart II, which shows the daily incidence of such cases both during the voyage and among the troops after debarkation. (See Chart II.)

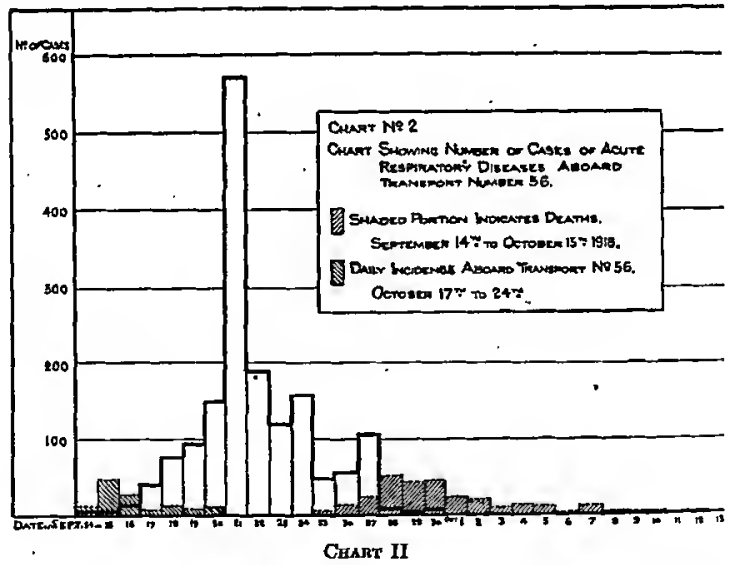

The ship reached an English port on September 21, the high point of the epidemic, and it was probably the debarkation of troops that prevented the further spread of the disease.

The ship's sanitary report shows that early in the voyage sanitary conditions on board were satisfactory, but that on September 21, when the great incidence occurred, great difficulty was experienced 
in properly caring for the patients, and the general sanitary condition became bad.

Owing to transportation difficulties it required several days to get all the sick off the vessel, and they were not all clear of ber until September 25. The troops not ill were sent to an American rest camp in the vicinity. During the period from September 23 to September 27 many cases developed in this camp, which appear in $\cdots$ Chart II, but by October 1 the epidemic bad practically ceased. The conditions in the rest camp were better than on. board ship, but even then there was much overcrowding, the camp containing 29 per cent. above its normal capacity. (See Chart III.)

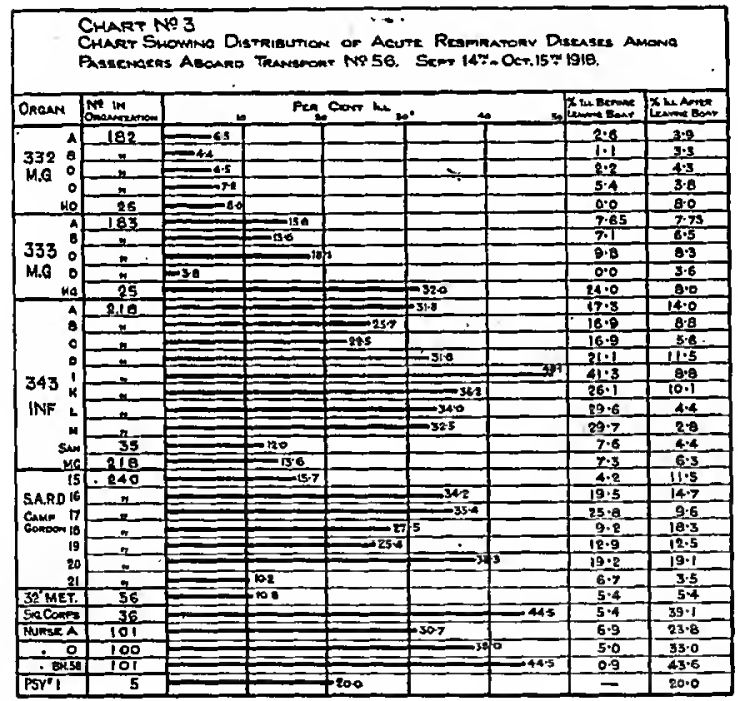

CEAFer III

In Chart III the incidence among the various organizations on. board will be found. It will be noted that some units had a greater number become ill before leaving the ship, others after. The nurses in particular showed a much higber incidence on shore than before landing. This is easily explained by the fact that they were assigned to duty on the ship and in the various hospitals caring for the ill soldiers.

Chart IV was prepared in order to determine how many cases developed after arrival in hospital. It will be seen that 317. cases, 
or 74.3 per cent., of the total had already developed before the cases were hospitalized. A few cases developed during the first and second days after admission, and in one hospital there was a considerable outhreak twelve to thirteen days later. (See Chart IV.)

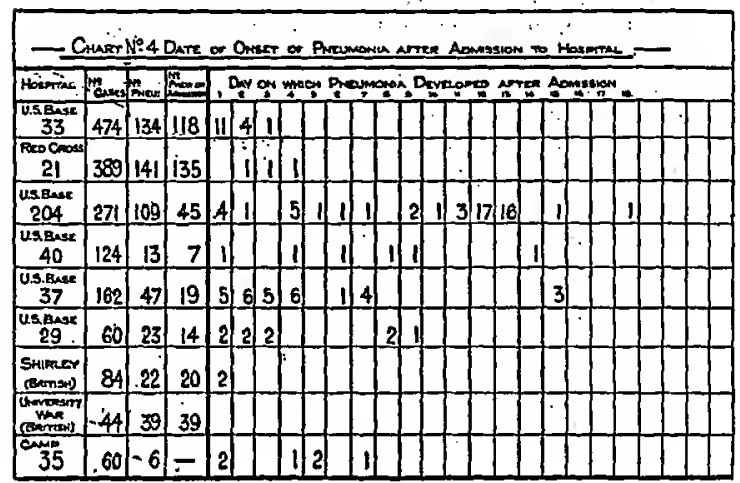

Ceart IV

In one hospital, which was located 180 miles from the port of debarkation, 96 per cent. of the cases admitted already had pneumonia on arrival, while in another hospital, distant only cight miles, only 41.5 per cent. had pneumonia on arrival.

The uniformly high death-rate of the pneumonia is shown in Chart V, which gives the percentage dying in each hospital. It may be said that in the two British hospitals listed therein, where the mortality was very high, the cases were practically morihund on admission, and at C.H. 35 there were post-measles pneumonia. In general, however, the severity of the disease seemed to bear some direct relation to the distance the patients were transported. (See Chart V.)

In order to gain some idea about the general condition of the troops, information was ohtained of the size of their home towns. This data is shown in Chart VI. It appears that two-thirds of the patients came from towns having a population under 6000 . As to the State from which they came it was found that about one-quarter were from Wisconsin and a considerable proportion were from Minnesota and Illimois. A study of their pre-war occupations disclosed the fact that about 58 per cent. were from farms. (See Chart VI.)

It is interesting to note the length of time that these patients had heen in the service. In Chart VII it will be seen that $4 \mathrm{I}$ per cent. hegan their military training in July, 23 per cent. in June and 10 
per cent. in May, 1918. They were therefore for the most part not hardened to the conditions. of warfare, and hence were particularly susceptible to a virulent infection. - (See Chart VII:)

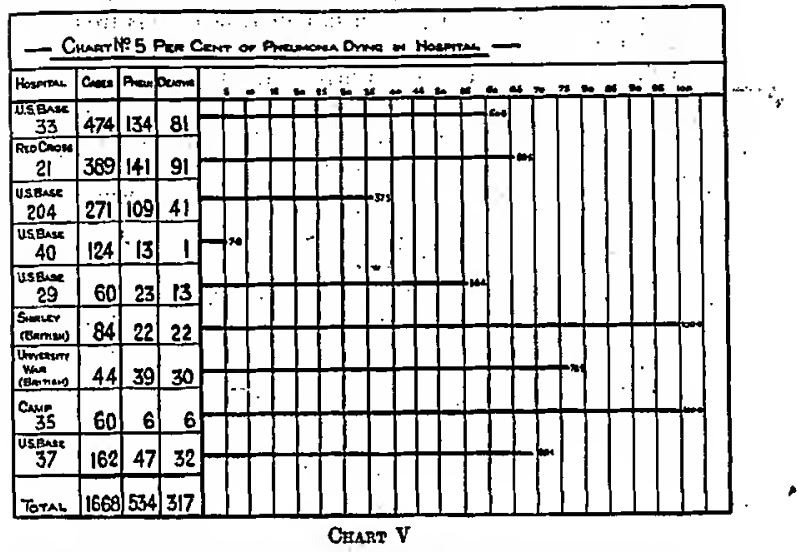

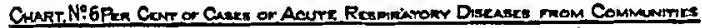

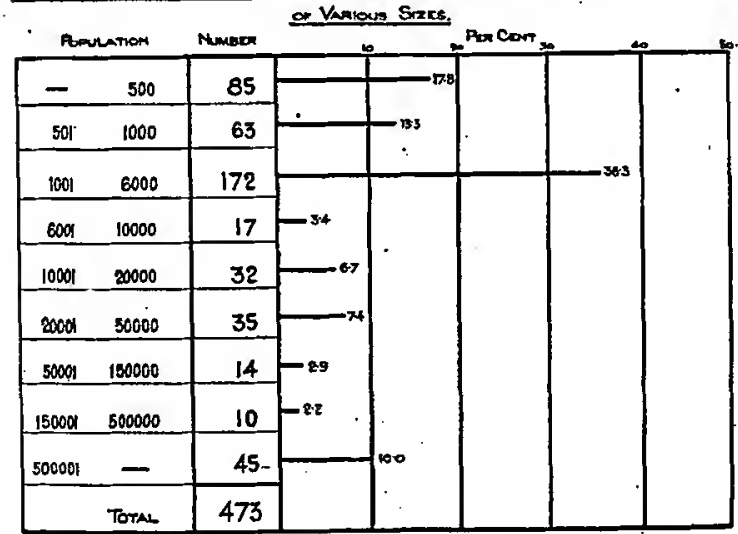

Canar VI

Information was asked from many concerning the details of their journey. Considerable evidence of debjlitating conditions was 
obtained. For instance, practically all complained that the shower bath which they had once or twice during the voyage was a severe ordeal. They said they were obliged to remain undressed, without covering, for a considerable period and then passed through a shower of sea-water. Many of them dated their colds from these batbs. They also complained that the food issued in the ration was unpalatahle and that they ate but little of it. Instead, they bought such articles of food as crackers, sardines and candy at the Canteen and ate at irregular intervals. Altogether, their method of obtaining food was sufficient to derange their digestive systems and probahly did not give sufficient nourishment. Most of the men who became

- CHART N: 7 LENGTH OF MILITARY SERVICE. -

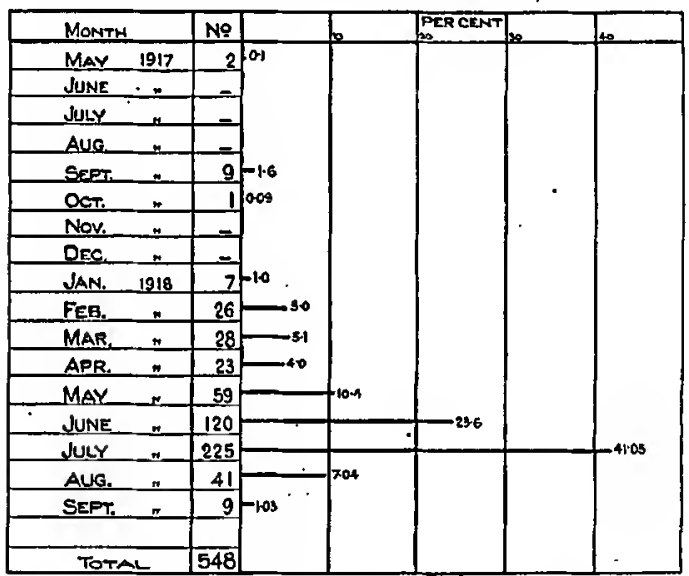

Cuate VII

ill had to sleep in hammocks. They complained that the lights were on all night and that the air in their quarters was foul, so that they were unable to sleep. It is evident that the nervous tension, which was quite unavoidable, owing to the circumstances of the voyage, made it impossible for the men to receive proper rest during the trip.

Inquiries were made relative to the illnesses which patients bad bad during the previous six months. These disclosed the fact that only about $126 \mathrm{had}$ been ill. The illnesses complained of in order of their frequency were measles, gastric disturbances, rheumatism, malaria, mumps, pneumonia and influenza. The number giving a past history of pneumonia within six months was eight and of influenza seven. 
To sum up, "Transport 56" arrived at a.British port with 5951 troops. It left the United States on September 14 and arrived on September 21. On the day of arrival 574 cases of influenza developed. By October 15, 1668 cases had developed, which is about 28 per cent. of the total number of troops. Of those who thus became ill; 534, or 32 per cent., were complicated by pneumonia, and of these 317 , or 19 per cent., died. Of those who developed pneumonia, 59.3 per cent. died. These figures are strikingly like those previously given for the entire epidemic in England.

The morbidity and mortality by weeks for this epidemic are shown in Table II.

TABLE II.-INCIDENCE - AND DEATH.

Rate per 1000 per month from influenza. Transport 56. First epidemic.

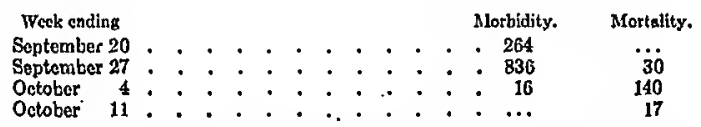

In marked contrast to this experience is the next voyage of the same transport. She again 'left the United States on October 17 and arrived in England on October 24, with scarcely more than a normal amount of sick, although a mild epidemic had been in progress during the trip. The incidence of infivenza on the second trip is also indicated in Chart II.

The following extracts from the report of the transport surgeon are of extreme interest:

"Troops were all examined and their temperatures taken before the sbip sailed and over 167 cases of influenza removed to shore.

"A general daily examination was made of all the troops and an evening temperature taken of the units by a medical officer.

"All on board were treated as contacts. Gauze masks were worn by all troops and the nose and throat sprayed with iodin and albolene solution, $1 \mathrm{gr}$. to $1 \mathrm{oz}$., twice daily. The last spraying was done before bedtime.

"The first day out of port, from 4 P.M., October 17 to October 18, 7 A.M., 11 new cases were reported. Second day to October 19, 7 A.a., 47 ; third day to October 20, 7 A.M., 17; fourth day to October 21, 7 A.M., 8; fifth day to October 22, 7 A.A1., 14; sixth day to October 23, 7 A.M.; 9; seventh day to October 24, 7 A.M., 11. These cases include 11 not of influenzal origin.

"Fifteen cases of pneumonia developed.

"Conclusion. These precautions seem to control an undoubted epidemic." 
This epidemic of 117 . cases among 5430 troops, with 15 cases of pneumonia and no deaths at sea, showed an incidence of 86 per 1000 per month; and 13 per cent. of the total cases of influenza developed pneumonia. It is further noteworthy that no increase in the epidemic occurred after deharkation.

From the second voyage of "Transport 56" it might be concluded that the measures taken-namely, masking of all souls on board, spraying daily and segregation of those with fever-prevented a widespread epidemic. This conclusion is not justified, however, because it happened that at about the same time another transport, the "Anchises," from the same port of embarkation, and loaded with troops from the same camp in the United States arrived at a British port with no cases of influenza, despite the fact that the only precautions taken were daily observation of the temperatures and segregation of those with fever. Further examination disclosed the fact that the troops on both these ships had passed through an epidemic before sailing and were therefore made up of those who had resisted this infection.

Epidemic of "Convor 46." The first trip of "Transport 56" shows what happened on a fast ship. The following brief account of what occurred on a slower vessel is also worthy of note: Steamship) "Nestor" left New York on September 17 with 2807 troops on board. No illness appeared until two days out, at which time several cases of influenza appeared in one hold. The ship put in at Sydney, N. S., on September 20, and Colonel Spitska, the S. M. O., insisted that all sick, together with contacts; he landed. This was done and somewhat over 600 men were put ashore.

The ship then proceeded on her voyage, and en route somewhere in the vicinity of 60 per cent. of all those on hoard developed influenza. Many of these had recovered by the time she reached port on October 2. There were 21 deaths at sea, or 9.5 per thousand, about 19 per thousand per month. The incidence of influenza was somewhere in the neighhorhood of 1200 per thousand per month. 'The sanitary conditions on hoard the transport were bad. She was overcrowded and the ventilation was poor.

These two ship epidemics present the two extremes found. In one instance a fast ship with the epidemic hreaking out toward the end of the voyage and checked by deharkation, in the other a slow ship with an epidemic raging for two weeks and on the decline when she reached port. Other ships presented similar or intermediate pictures. The epidemic in this case suggests what a very serious state of affairs might have occurred in "Transport 56 " had not the troops been promptly deharked.

Epideaic at Base Hospital 29. As an example of how fixed personnel occasionally became involved a brief statement of an epidemic occurring among the personnel of Base Hospital 29 may be of interest. This hospital received a convoy of 60 cases of influenza 
from "Transport 56". on September 24. Table III shows the incidence of influenza and the death-rate among the hospital personnel following the receipt of the convoy.

TABLE III.- SHOWING INCIDENCE INFLUENZA AND DEATH-RATE PER

1000 PER MONTH. PERSONNEL OF RASE HOSPITAL 29.

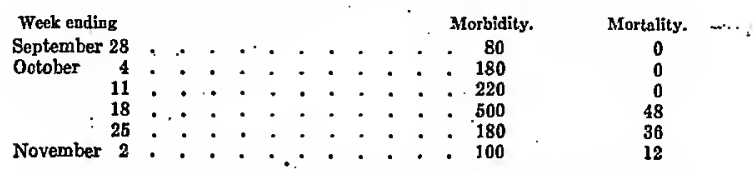

Other hospital personnels were affected, but not as seriously. The high incidence in Base Hospital 29 can be explained very likely hy the fact that it is situated in a crowded portion of London where influenza was quite prevalent among the local population. Also, perhaps, partly because this organization, having fairly recently come from a high dry climate in the States, may have been less acclimatized to the damp weather prevalent in England than were other organizations.

Clinical Fearures of Disease. To get an accurate description of the clinical features of the disease undcr discussion an attempt has been made to collect and consolidate the observations of the medical officcrs in charge of the cases in all of the American hospitals in. Ingland. From the reports received and from the observations of officers visiting the several hospitals in turn it hecomes apparent that we are dealing with a definite clinical entity, presenting essentially similar features in cases derived from different sources and localities.

The patients were largely received from incoming transports from America, though a certain number developed among the medical and nursing personnel and patients in hospitals for other conditions, apparently as a result of direct contact. The state of advancement of the disense varied somewhat among the groups received from various ships. Thus in the case of the rapid "Transport 56," the epidemic had only assumed alarming proportions on the day of arrival in port, so that many cases developed, and practically all the deaths occurred on shore.

With the slower ships, such as the "Nestor," taking from fourteen to fifteen days, on the other hand, the epidemic had often apparently involved the greater portion of the susceptible persons on board, and many of the patients received by the hospitals after the ship's arrival were in the most serious stages of the disease.

Histories. were not always ohtainahle, but in general the stories told and the onset observed in the cases that developed under observation present a similar picture. 
Onser. The onset is, as a rule, sudden, with fever, chilly sensations or rigors and of tentimes a marked degree of prostration. Aching in the extremities and back and chest were of ten complained of, and headaches occurred in a considerable proportion. Muscle tenderness was frequent. Previously to this sudden onset many of the patients had been quite well. This applies particularly to the cases that developed in England, but in many of those that developed on board ship there were histories of common colds, sea sickness and exhaustion for several days previously. Coughing, with a mucopurulent sputum, occurred from the start in practically all of the cases. In addition a certain number showed a definite coryza, with sneeging, not, however, with conjunctivitis as in measles. Sore-throat was occasionally present, but was not a common feature. Hoarseness may occur in the later stages, but not usually in the beginning. ${ }^{2}$ The sputum even on the first day or two of the disease was occasionally streaked with fresh blood, and epistaxis was often seen. The pulse in such early cases was usually full and bounding, 'of good tension and the rate varying with the temperature from $80^{\circ}$ to $120^{\circ}$.

UnCOMPLICATEd INFLUENZA. All cases having started as outlined above, developed further in one of two definite ways: They either ran an uneventful course of from three to seven days, ending in recovery, or they developed a most serious type of bronchopneumonia. The former group, which we may call simple influenza, comprised from 60 to 70 per cent. of the whole. Of the course of these uncomplicated cases there is nothing of any great moment to

* In regard to laryugeal involvemeat tho following report, hy Captaia Williau M. Bane, of Baso Hospital No. 29, is of interest:

"Among the 235 eases of influeaza and the 54 eases of pneumon a which have been eared for in this hospital from September 1, 1918, to October 25, 1018, there havo oecurred $\theta$ cases of laryngitis, 6 of which developed oaly hoursencs nad eounh and 3 a comploto àphonis.

"The type observed has heen invariably an acuto eatarrlial aryngitis. The active eause is iafectioa hy invading organisms which gain entranco into tho mucosa when its resistance has been lowered by ono or more of ths following: Irritating cough, toxins evolved from diseased nasal mucosa, accessory sinuses or pharyns; inspiration of air improperly moistened, warmed and filtered by rengoa of nisal obstruetion. Tho infuenrss and pacumonins almost all show inflamed and swollen mucous membranes in the nose and thront, and mouth breathing is commonly ohserved. Sinusitig, cspecistly frontal, has been very common.

"Of the suhjectivo symptoms, alterations in voice and tho cough have been constant, but pain has been very uncommos. Ohjectively, very slight swelling and hyperemia of the cords and adjacent mucosa have besn olsserved, hut no cases in which there was any edema, hemorrhagic aroas or vlcerations have besn scen.

"As to prognosis it seems that the infeetion, although quito virulent, has attacked the upper respiratory tract much less severely thas the lower part, so that the outcome from the Isryagitis is ustally good.

"Trentment has consisted essentially of limitation in the use of the voice, complcte rest where possihle and mild inhalations of tincturo benzoin comp. and steam every three hours. The inhalations were not only beneficial to tho mucosa of tho throat but usually very soothing to the patient with severe bronchitis. Approprinto trcatweat to the nose, accessory sinuses and tonsils is essential. Ths cases with completc aphonia regnined the use of the voice in about three days, followed hy a prolonged period of hoarseness. Another case with nphonia proved to be hysterical." 
relate. The fever continued generally from one to seven days, but usually from two to four days, and then fell either by crisis or rapid lysis to normal. With the fall in temperature the toxic symptoms cleared, if they had not previously, and oftentimes the patients would feel entirely recovered. In many cases a considerable degree of prostration persisted for several days. The cough usually persisted for a week or more and the patients continued to raise a small amount of purulent sputum after they were, in other respects, quite well. During the fever there was nearly always a considerable degree of anorexia and often profuse sweating. Abnormal signs in the chest in the cases of simple influenza were often entirely lacking, or in a certain number there' might be a few scattered rales and ronchi. The patients were usually thushed and occasionally slightly dusky in appearance. The eyelids often were slightly puffy. Sometimes transient erythemas were noted over the trunk or extremities, but there was no characteristic exanthem or enanthem. To sum up: the picture was that of an acute infection of the upper respiratory tract, with very sudden onset and marked toxemia, and because of its epidemic form, evidently highly contagious.

Influenza Pneumonia. We come now to the second type of the disease, which in reality seems to constitute what might be termed a superimposed epidemic and which took the form of an exceedingly fatal typc of bronchopneumonia closely associated with a purulent hronchitis, and which is responsible for practically all the dcaths. occurring in the cpidemic. This bronchopneumonia, though most prohiably caused by a different infectious agent from the original disease, hears a close relationship to the latter, inasmuch as it presents some very characteristic features which differentiate it from ordinary pneumonia, and because, so far as we can leam, it never appears out of a clear sky ira heal thy individual hut only in persons already suffering from influenza.

The pneumonia nay begin anywhere in the course of the simple influenza, sometimes as early as the'second day. It is ushered in by an apparent increase in the toxicity of the patient, hy an increase in the rate of respiration and the early development of eyanosis. The physical signs of consolidation appear usually at one or both bases, though occasionally consolidation has first heen noted in one of the upper lohes. At the same time there is generally found an increase in the amount of moisture in the chest, as shown hy the presence of numerous moist rales scattered throughout. The sputum becomes more purulent and contains considerable quantities of fresh hlood. Epistaxis also was exceedingly frequent. The course may be exceedingly fulminating; death occurring as early as the second or third day. In such cases the signs of consolidation rapidly extend, one lohe being involved after another in an almost explosive fashion, so that death may occur from mechanical asphyxia so great is the lung involvement. Other cases run a more prolonged course. 
Patients may continue with the disease for two weeks and ultimately succumb. In such the consolidation is liable not to be particularly extensive, but the purulent bronchitis is a more prominent feature and the cause of death apparently is toxemia. Between these two types all grades of intermediate varieties were found. The temperature curve in the fulminating cases was apt to be continued high anywhere from $102^{\circ}$ to $105^{\circ}$, the pulse varying from 100 to 130 . Shortly-before death the temperature would rapidly drop and the pulse rapidly rise. In the more chronic cases tbe temperature was liable to be very irregular, a septic temperature in fact. The cases that recovered usually showed a gradual lysis, though the crisis was occasionally observed. A pseudocrisis, followed by a resumption of fever of the irregular type, was more frequent. The respiration was nearly always increased in rate, and often shortly before death exceedingly rapid, sometimes as higb as sixty per minute. It was apparently a tachypnea rather than a true dyspnea, however, for except in the moribund cases it was usually not a source of discomfort to the patient. Certain very striking differences between the influenza pneumonia and ordinary lobar pneumonia have impressed themselves upon practically all the officers who bave had patients in their charge. In the first place the general appearance of the patient is unlike the usual pneumonia. In spite of his rapid breathing there is a striking absence of orthopnea; in fact, he usually lies flat by preference. There is almost never any pleural pain, and although an occasional friction rub has been heard it is exceptional. The painful grunting breathing of lobar pneumonia is almost invariably absent. The tenacious, tawny or rusty sputum of true pneumonia is not seen, but instead an abundant mucopurulent sputum, with considerable fresh, bright red blood is the rule. Another characteristic feature is the early developing and profound cyanosis seen in all the severer cases. It is of a peculiar tint, a decp lavender or heliotrope. As a rule the intensity of this cyanosis bears no definite relationship to the degree of consolidation. It may be as deep in the primarily purulent bronchitis cases in which there is little consolidation as in the fulminating cases with extensive consolidation. - Moreover, no cause for it can be discovered in the circulation. No dilatation of the rigbt heart can be made out on physical examination, and this is in part borne out by the autopsy findings; nor is the pulse necessarily of poor quality nor the bloodpressure low. A recent paper by Hoover ${ }^{3}$ is extremely interesting in this connection, and his views on the importance of foam in the bronchial tree may explain the non-relationship of cyanosis and degree of consolidation seen in these cases. As Hoover points out the presence of foam in the bronchial tree will cause a marked

- Moisture in the Air Spaces of the Lunge and Ozygen Therapy, Jour. Am. Med, Assn., September 14, 1919, 1xxi, 880. 
hindrance to gas, exchange in the lungs, and as most of these cases of influenza pneumonia have considerable moisture in the chest, their cyanosis may well be explained on that basis:

It should also be emphasized that epistaxis is frequent and highly characteristic of the disease.

Certain other noteworthy manifestations and complications have been observed. A moderate number of cases presented the signs of meningismus, and these were relieved by lumbar puncture, the fluid being sterile, but under pressure. Another striking occurrence was the development; in a few cases; nearly every hospital had one or two, of a subcutaneous emphysema of the neck and upper chest. This was unquestionably of mechanical origin, for it was never accompanied by any inflammatory process. It was as though air had been introduced beneath the skin and was unaccompanied by any redness or induration. The cause of this phenomenon has not been definitely established, but in one case that came to autopsy the emphysema was found to extend downward along the course of the trachea through the mediastinum and about the pericardium. Moreover, several cases at autopsy which had not presented emphysema of the neck during life showed emphysema in the mediastinum and about the pericardium, and one showed blebs of air over the visceral plcura. It seemed most likely that the air escaped into the lung, and following the course of the large bronchi-made its way through thc lung root and along the course of the trachea to the neck. In no instance was this condition associated with pneumothorax, nor was any case found at autopsy in which there might have been an escape of air from the lung through adhesions to the mediastinum. Rupture of the trachea or main bronchi was not found.

An occurrence which may or may not be accidental was the development. in some of the cases, which had either had or were having influenza pneumonia, of meningococcus meningitis. This occurred in at least 30 cases, 20 of them being in one hospital. This uneven distribution suggests that the incidence of cerebrospinal fever was not causally related to the influenza; except in so far as the influenza might have been predisposing. Three cases of pneumococcus meningitis were reported.

Evidence of disease of the accessory sinuses of the nose was frequently found, as was also purulent otitis media. It is interesting to note in this connection that out of 26 autopsies in which the head was explored, empyema of one or more of the accessory sinuses was found in $21^{\circ}$.

One.case of undoubted acute endocarditis was found clinically and two at autopsy.: Systolic murmurs at the apex were not infrequent; and in the cases that recovered, rapidly disappeared. Pericardial friction rubs have not been.reported.

Abdominal complications beyond the distention often seen in pneumonia were lacking. Enlargement of the spleen demonstrable 
on physical examination was rare. A few cases presented nausea and vomiting and acute abdominal pain.

Jaundice occurred in a small percentage of the cases.

An exceedingly interesting complication was observed at American Red Cross Hospital 4. Fifteen cases presented swollen, painful feet, and several of these showed acute red inflammatory arens over the toes and instep from 1 to $2 \mathrm{~cm}$. in diameter. Two cases also showed blebs and bullæ over the shins. It was thought that there might have been septic thrombosis or embolism, the red areas being similar to those described by Osler in malignant endocarditis. - A negative feature of the epidemic, which is rather striking, is the comparatively low incidence of empyema.

Clinical Pathoiogy. Sputum. The gross appearance of the sputum has already been described. The points to be emphasized in the pneumonia cases are its abundance and its striking difference from ordinary pneumonic sputum, in that in place of a tenacious rusty sputum there is found a yellow purulent sputum with abundant streaks of fresh blood.

Films of the sputum show usually a varied flora. Influenza-like bacilli wcre frequently found but so, too, were a variety of other organisms, having, for example, the morphology of pneumococcus or streptococcus.

Blood. Blood counts wcre not done systematically, but when done were of considerable interest. In the simple influenza tbe white count was usually low, 5000 cells per $\mathrm{cm}$. being not uncommon. The pneumonia cases also often showed a leukopenia, sometimes a slight lcukocytosis, rarely over 12,000 to 14,000 , and practically never over 20,000 . The fatal cases usually showed a leukopenia. This is in very striking contrast to ordinary pneumonia.

Urine. The urine showed the ordinary type of febrile urine, a moderate amount of albumin and tube casts being present particularly in the pneumonia cases. Blood was rarely seen.

TREATMFNT. The preventive measures taken were entirely along the lines of isolation and hygiene, and are dealt with under tbe heading Hospitalization.

No specific therapy was employed except in one instance, and since the causative organisms were not definitely known, no specific therapy could be used except in an entirely empirical way. At the beginning of the outbreak it was thought that the pneumonia was very likely due to the streptococcus, and therefore a sensitized streptococcus vaccine obtained through the kindness of Lieut.-Col. Harvey, R.A.M.C., from the vaccine laboratory, was tried in a small series of cases, without, however, any apparent benefit to the patient.

Oxygen has been used fairly extensively without any very striking results. The patients might or might not improve temporarily, but the course of the disease does not usually seem to be materially altered. At one hospital the Haldane feld apparatus for oxygen 
administration was used. It was found to he a convenient way of giving oxygen, but beyond that no extraordinary beneficial effect was noted.

Further than this the usual symptomatic treatment of pneumonia has heen carried out. Digitalis in some form has heen commonly employed as well as camphor and other stimulants, and morphin or opium where indicated. At some of the hospitals urotropin has been used as routine.

Fluids have heen forced hy mouth, rectally and suhpectorally. It is felt that the hope lies in propbylaxis. Should the etiological factor be proved it should be possible to immunize against this disease. The immunity thus secured plus better methods of sanitation, particularly on board transports, sbould prevent a recurrence of the epidemic.

Hosprtalization. The matter of proper hospitalization of this sudden influx of contagious cases presented certain difficulties, but in general it was accomplished with all possihle promptness, and except for. the fact that in certain instances patients had to be transported for comparatively long distances on ambulance trains to reach hospitals, which is unquestionahly undesirable, it is not thougbt tbat any cases suffered for want of proper hospital care.

In hospital, strict isolation was carried out from the start. Not only were the influenza cases and pneumonia cases segregated in separate wards, but in all the American hospitals tbey .were screened one from anotber. The most usual method of screening was hy means of sbeets bung from wires. Fig. 1 shows tbis method in practice in a ward at Base Hospital 29. 
Since the pneumonia may be due to a number of different infecting organisms, we bclieve that the importance of the prevention of eross infeetion by droplet infection by the usc of scrcens cannot be too strongly emphasized.

In addition to these measures all persomel while on duty in the wards eonstantly wore gauze masks over the mouth and nose and were obliged to douche their nasal and oral eavities with some milkl antiseptic solution onee daily.

Pathological Anatosiy. A summary of the anatomieal diagnoses recorded are shown in Table IV. Pneumonia was found in 99 per cent. of the fatal enses, and in 80 per eent. was apparcntly bronehial in distribution. The most common complication was fibrinous pleurisy, 39 per eent. Pleural efiusions and empyemas wcre not uneommon, but were mueh less frequent than in the epidemics of strcptococcus pneumonia occurring in the United States last winter. (See Table IV.)

Dilatation of the right leart was noted very frequently by some observers, less frequently by others. The difference in percentnges noted may be due to individual differences in interpretation of the findings. A moderate enlargement of the spleen was noted in about half the cases and cloudy swelling of the liver and kidneys were recorded somewhat less frequently than one would expect in acute infections of this type. One finding which was ratlucr common was clironic passive congestion of the liver.

Among the rarcr lesions not noted in the table wcre peritonitis, which oceurred in a few instances apparently as an cxtension from the pleurisy, and meningitis duc to the influcnza bacillus in two instances, to the streptococcus in one, to a mixture of thesc two organisms in onc and in two instanees to the pneumococcus. In cases in which the brain was examined it was common to find the pin distended with fluid and the eortex intensely injected. Onc might include under the eomplications the cases of meningococcus meningitis which followed bronclopneumonia, as both these meningitides and the pneumonias were probably sequele to the original grip infection.

\footnotetext{
- Tho observations on tho pathology and bacteriology of this epidemic aro compiled from data and material coatributed by workers at tha various laboratories in this base section:

Major W. W. Willíns, Base Hospital No. 20.

Captain A. W. Stahl, Baso Hospital No. 204.

Captain G. A. Sorgatz, Camp Hospital No. 40.

Captain M. B. Beecroft, Base Hospital No. 37.

Lieut. R. S. Stauffer, Baso Laboratory.

lieut. R. R. Simmons, Base Hospital No. 33.

licut. F. B. Harrington, Camp Hospital No. 35.

Lieut. T. M. Marks, Base Hospital No. 40.

Liout. D. C. Leo, A. R. C. M. Hospital No. 4.

Licut. E. D. MelBride, A. R. C. M. No. 21.
} 
ALADER, MEANS, HOPKINS: FPIDEMIC OF INFLUENZA 387

\begin{tabular}{|c|c|c|c|c|c|c|c|c|c|}
\hline 菢 & & 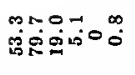 & 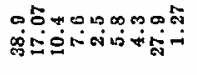 & 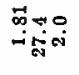 & $\sin _{0}^{\circ}$ & rị & 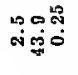 & 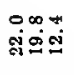 & $\begin{array}{l}00 \\
20\end{array}$ \\
\hline$\stackrel{\dot{B}}{\stackrel{3}{2}}$ & 范 & 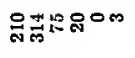 & 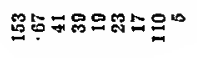 & $\stackrel{\infty}{\circ}$ & 900 & $\stackrel{\square}{=}$ & 옴 & 品央: & ్ㅐㅁำ \\
\hline $\begin{array}{l}=30 \\
=0 \\
=8\end{array}$ & $\overrightarrow{0}$ & 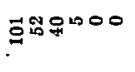 & 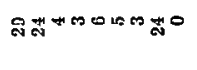 & $\infty \infty 0$ & $000-$ & ON & $0 \infty 0$ & ONO & 000 \\
\hline \begin{tabular}{l}
0.4 \\
$\vdots$ \\
\hdashline
\end{tabular} & $a$ & 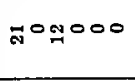 & 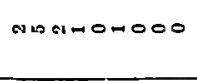 & oivo & DNOO & 00 & $0+0$ & $\infty 00$ & 000 \\
\hline 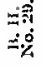 & 잉 & rgodor & $+1+\infty 0-100$ & noo & $1-100$ & $-\infty$ & $0 \infty 0$ & NoO & 000 \\
\hline
\end{tabular}

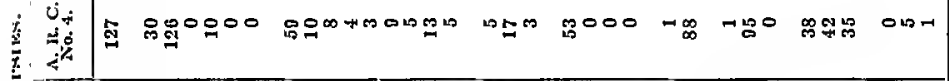

में

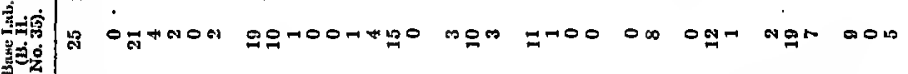
ma fin

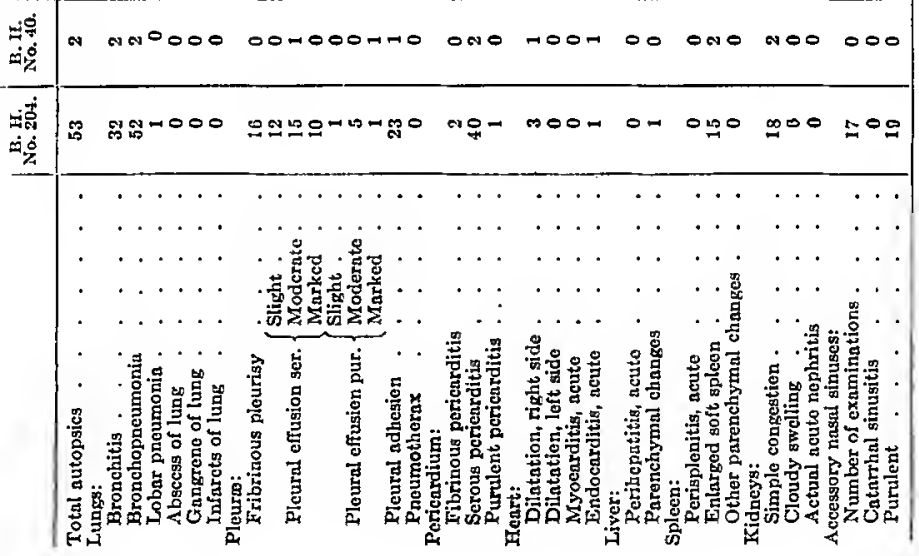


Nasal Sinusitis. A lesion whieh intercsted us considerably was a purulent inflammation of the sphenoid or ethmoid sinuses. This seldom gave pronouneed elinieal symptoms, but was found in 69 per cent. of the eases in whieh the sinuses were examined postmortem-at one hospital in 16 out of 17 enses. It was striking from the baeteriological side that the same organisms as were found in these infeeted sinuscs, were usually present in the eonsolidatcd lung of the same ease. "This faet snggested that these sinuses might be the primary foeus of infeetion, a possibility whieh was also suggested by Major FL. F. Rohertson ${ }^{5}$ in conneetion with an earlier influenza epidemie.

Penibronchisl Pneumonia. The most important lesion apparently was the pncumonia, and this varied remarkably from ease to ease, botlı anatomieally and baeteriologically. In the earlier eases the lung showed fairly miform consolidation, approximating a typical lobar pneumonia, and differing from it chicfly in the hemorrhagic appenranee of the lung and the moistness of thic consolidated areas. From some of thesc massive pneumonias only tie influenza bacillus was recovered on eulture. In the later cases the consolidation was remarkably patehy, and toward the end of thc cpidemic eases began to appear which showed macroseopically a purulent bronchitis and practically no pneumonia. These last cases resembled strikingly those seen in an epidemic in France in Dceember, 1917, which were uneomplicated influenza bacillus infections. Of the bronchopneumonias many showed minute abscesses, some showcd extensive hemorrhages, many pronounced edema of the unconsolidated areas and in those with pleurnl effusions the pieture was eompliented by a eompression ateleetasis. These pneumonias were anatomically not one disease but a variety of terminal processes grafted on some original infection.

It is impossible, therefore, to deseribe any lesion typieal of all eascs. However, the majority of the lungs examined had certain eommon eharaeteristies. They were, as a rule, very voluminous and contained eonsiderable air, but firm nodnles could be felt in the eushiony lung substanee. Toward the posterior portion of the upper lobe and the base of the lower lobe these discrete masses were replaeed by a solid block of airless lung. On seetion the eonsolidated areas stood out rather sharply, and frcquently were in the form of a pyramid, with the base against the pleural surface of the lung. Scattered through them were dots and lines of opaque yellowishgray material, frequently with points of blaek anthracotie pigment in the center, varying from $0.5 \mathrm{~mm}$. to 3 or $4 \mathrm{~mm}$. in thickness. In some eases these grny areas were firm and in others could be squeezed out as drops of thick pus. Between these foei the con- 
solidated tissue was granular, rather moist, sometimes gray, but more frequently a brilliant crimson. Again, between these eompletely consolidated masses the lung tissue was often nearly solid, moist and red, apparently representing what Baehr hns deseribed as an explosive terminal extension of the pneumonia.

The arterial trunks were frce, the larger broneli and traehea intensely inflamed with briglit crimsor mueosa and a small amount of purulent or fibrinous exudate.

Mieroseopienlly the most interesting changes were in the smaller bronchi. 'These were frequently' represented by a eolleetion of leukoeytes bordered on one side by the mueosa and museular vall of the bronehus and on the other side emerging indefinitely with alveoli filled with purulent exudate. In other eases only shreds of bronehial epitlelium conld be unale out, remaining here and there along the wall, and in many sections no remnants of the bronelial wall could be made out, the bronchi being apparently represented by little pools of pus, each lying close to an artery and a vein and bordered only by inflamed alveoli. The air cells immediately around thesc disintegrated broncli were usually filled with pus, but beyond these was a zone in which the exudate was, as a rule, cronpous, containing considerable fibrin, witl red cells, lenkocytes and epithelia in varying proportions. Not infrequently there were extensive areas of hemorrhage, in some of which the red cells lay within well-preserved alveoli and in others the lung framework had been swept awny.

It has not been possible to study all the eases microseopically or to eorrelate all the listologieal pictures with the baeterial findings. It appeared, however, that the feature common to nearly all the eases was what we may call an uleerative bronehitis and peribronchial pneumonin, the ulcerative process often resulting in a complete dissolntion of the walls of the smaller bronchi. The brealclown of this line of defence would make easy the aecess of any patlogenie organisms in the bronehial tract to the already injured lung tissue. This offers a possible explanation of the variety of baeteria encountered not only in the lung but in the other viseera and the blood stream and also of the frequeney of mixed infeetions.

BACTERIologY. The preliminary examination of sputum from the early eases of pneumonia showed a great variety of organisms, witl no striking predominanee of one type, and it was thought that the surest evidenee as to the identity of the infeeting agent eould be obtained from eultures postmortem. The results of eultures from eonsolidated lungs made at the various laboratories in the base seetion are summarized in 'l'able $\mathrm{V}$. Here, again, a great variety of baeteria were fouml, the organism most frequently met with being one elosely resembling the influenza baeillus of Pfeiller. (See Table V.) 


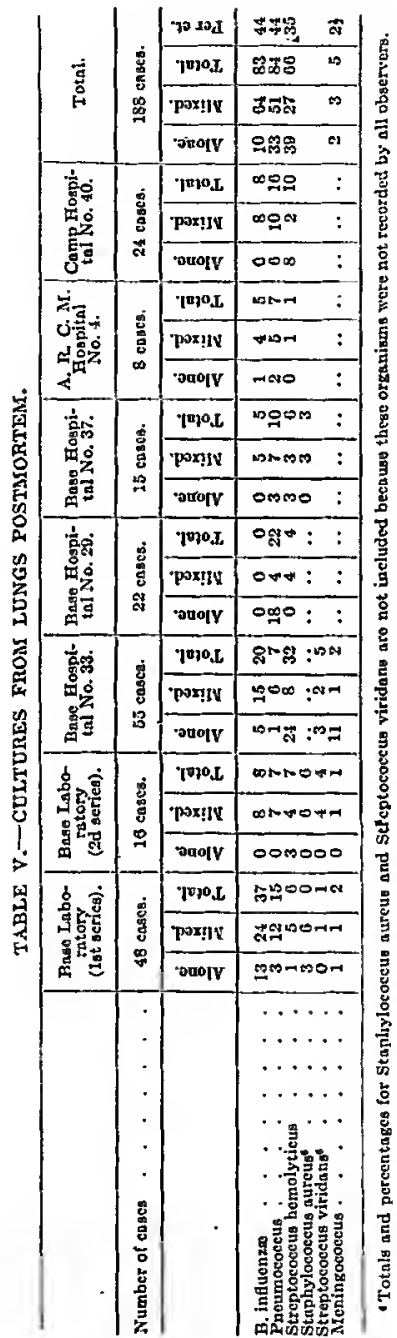


Influmenza BacluLus. All the organisms reported as influenza bacillus gave eharacteristic delicate growth on subeulture on bloodagar, and morpbologieally were minute eoceo-bacilli or minute rods. In older cultures long tliread-like forms and also swollen oval or pear-shaped forms were sometimes seen. A eonsiderable number of these strains were planted in parallel on serum-agar and on whole blood-agar, and all thosc tested showed elaracteristie inability to grow on serum-agar. On account of the rush of work it was impossible to complete the identification of all strains, especially during the first part of the epidemic. Up to the present we have also not succeeded in producing a satisfactory agglutinating serum for the identification of these organisms. As far as observed, lowever, they eorrespond to the usual deseription of $\mathrm{B}$. influenze.

PNeUnococcr. The majority of the pneumococci isolated werc tested for bile solubility and also for agglutinability in Group I, II, and III sera. At Base Hospital 29 inulin fermentations were also earried out. At this laboratory all the pneumococci recovered postmortem belonged to Group.IV. At the base laboratory we obtained two strains of Group I, two strains of Gromp II, five strains of Group III and 19 strains of Group IV. Of those classed as Group IV several slowed a sligbt agglutination in 1 to 20 dilution both in Group I and Group III serum and one strain agglutinated slightly in all three sera. The reaetions, howcver, in these eases were so feeblc when eompared with the eomplete agglutination which occurred when the Jomologous strains were employed that these organisms were elassified as Group IV. Whictler many of them may belong to one subtype of this hetcrogeneous group has not yet bcen determined.

Gram-NEGATIVE Diplococci. In the enrlier cases no record was made of the finding of Gram-negative diplococci in eultures from thc lung, as they wore regarded as being saprophytes from thic bronchi. On account of the frequency with which they occurred, not only in eultures from the lung but also in cultures from the heart's blood or splecn, the later strains were more carefully studied. Of these one pure eulture obtained from the lung agglutinated in Type I antimeningoeoccus serum (Gordon), and one whieh was found mixcd with influenza agglutinated in Type II. Another one assoeiated with the pneumococcus agglutinated with Lederles's polyvalent serum, but failed to agglutinate with any of Gordon's type sera. Of the others most strains produeed pigment on subculture or else grew in a dry mass which would not emulsify and werc disearded. The few which gave satisfactory cmulsion were tested but were not agglutinated by any sern at our disposal. Two strains of a number submitted by Capt. W. Fletcher, R.A.M.C., failcd to agglutinatc in any of the "Gordon" type scra but agglutinated in Type C of the Pastcur Institute. Two cultures wcre also obtained by Lieut. Simmons. Of the strains mentioned below, isolated by 
Lieut. Stauffer from the sputum and nasoplanynx, one agglutinated in polyvalent antimeningocoecus serum "Flexner" but not in any of the "Gordon" type sera. The remainder were inagglutinable. It is interesting that apparcntly 5 eases of meningococeus-pneumonia oecurred in this series.

Cultures frour otrea Visceira. The results of cultires from heart's blood and other viseera are summarized in Table VI. As the rountine procedure varied at different hospitals this serics is far less eompletc. Here, again, the pieture is confusing. In one ease the influenza baeillus, streptococeus and pneumoeoeeus wert: all isolated from the heart's blood. Anotler eonfusing factor was that Staphyloeocens albus and Grain-negative diplococei of the flavus and eatarchalis types were not infrequently recovered from the lieart's blood or from the spleen, which suggested that in these enses the bacterial flora of the respiratory traet gnined ensy aecess to the blood stream either shortly before or after death. One faet that seemed evident was that the pleural and perieardial efiusions wcre due either to the pnenmoeoceus or streptoeoeeus and not to the influenza-baeillus. (Scc Table VI.)

In order to bring ont more elearly these variations the reports from the various laboratories have been recorded separately in these tables and the reeords at the base laboratory divided into those obtained during the first part of the epidemie, nud a seeond series, donc during the later part when the eases were less numerons, and it was possible to work out the eultures more thoroughly.

Discussion of Postmoniem Culfures. The striking featurc of the postmortem bactcriological findings was the great variety of bacteria recovered. The findings variel first according to the period of the epidemic. During the first part of tlie cpidemic the influenza bacillus was prescut in most of the eases as far as our personal observation went, and frequently was the ouly organism recovered from the consolidated lung. As the cpidemie progressed this organism was less frequently recovered, and instances of pure influenza pne11monin were extremely rare. The findings also varied aceording to the portion of the lumg examined. Severnl bactcriologists reported that in cases in which the rccently involved portion of the lung gave a pire or a ncarly pure eulture of $B$. influenze the older areas showed pyogenic cocci alone, bcing mixed with a few influcnza bacilli. The findings also varied very strikingly from place to place. At Base Hospital 33 over 50 per cent. of the eases slowed hemolytic streptocoeei, while at most of the hospitals this type of infection was rare, and at Base Iospital 29, pneumococeus Group IV was recovered from every case antopsied.

The majority of the patients in this scries eame from one transport and became sick wlilc they were in elose contaet with each other, and were later distributed to the various hospitals in the scetion. It scemed elear, on epidemiologieal grounds, that the origi- 


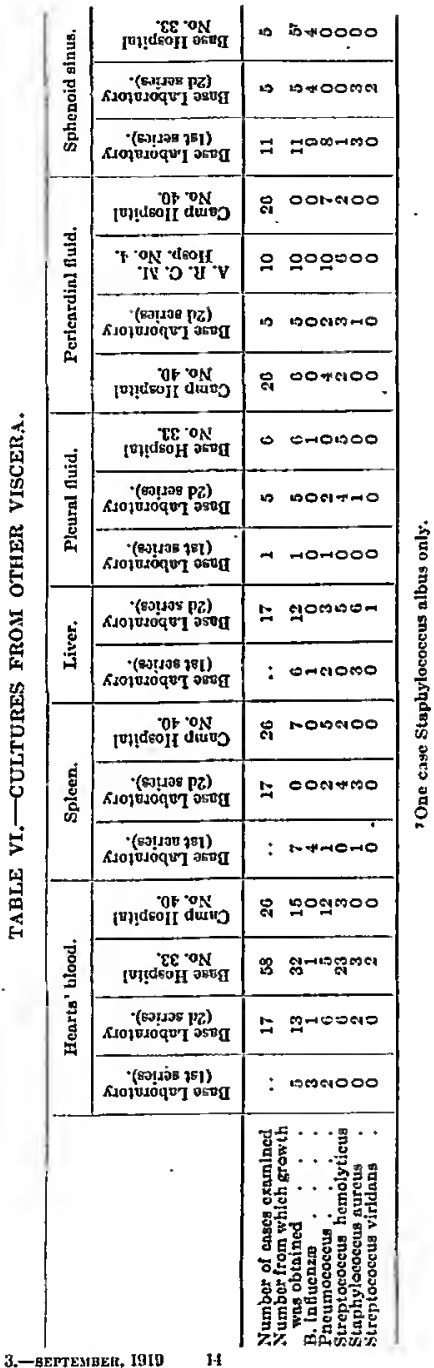


nal infection must have been due to onc microörganism, and we can only conclude that the various infections observed postmortem were terminal aftairs. The fact that certain types of infection predominated at certain hospitals suggested that the terminal infection occurred after admission to the lospital.

Tlic only organism found which could well have been the primary infecting agent was the influenza bacillus, and this was recovered from only 44 per cent. of all the cases. This figure may well be lower than the actual fact on account of the difficulty often found in cultivating this organism when we know it to be present. Its prevalcnce during the early part of the epidemic and in the recently involved portions of the lung both pointed toward its being the primary agent. In order to secure more definite cvidence on this point, cultures were made from blood and from sputum of paticnts during life.

Blood Cultunes. The blood cultures gave little information. When taken from uncomplicated influenza they were uniformly negative. A small percentage of those taken from cases of pneumonia showed the presence of pneumococcus or streptococcus.

\begin{tabular}{|c|c|c|c|c|}
\hline & $\begin{array}{c}\text { Base llospital } \\
\text { No. } 204 .\end{array}$ & $\begin{array}{l}\text { Ilnse lfospital } \\
\text { No. } 33 .\end{array}$ & $\begin{array}{c}\text { Bnse Hospilal } \\
\text { No. } 20 .\end{array}$ & $\begin{array}{c}\text { A. R. C. Hos- } \\
\text { oitni No. } 4 \text {. }\end{array}$ \\
\hline $\begin{array}{l}\text { Number of cultures } \\
\text { Pneumococcus } \\
\text { Streptococous hemolyti }\end{array}$ & $\begin{array}{rr}20 \\
\text { icus } \quad 0\end{array}$ & $\begin{array}{r}16 \\
0 \\
0 \\
18\end{array}$ & $\begin{array}{c}70 \\
4(6 \%) \\
2(3 \%)\end{array}$ & $\begin{array}{r}20 \\
8 \\
0 \\
12\end{array}$ \\
\hline
\end{tabular}

Sputum Culturas. The cultures from sputum were more helpful, though by no means conclusive in thcir results. Thirtytwo cases from "T'ransport 56," only 3 of which had definitc signs of pneumonia, were studied by Lieut. Stauffer. The sputum was olstained at the bedside, washed and injected immediately into the peritoneum of a mouse, and also plated directly on blood-agar. At the same time a swab from the nasopharynx was plated on bloodagar. (See Table VIII.) The influenza bacillus was recovered from the sputum in 75 per cent. of the cases and slightly less often from the nasopliaryngeal cultures. The pneumococcus was found in the sputum in 10 cases and in the nasopharynx in 6 . Seven of the latter were tested for agglutinability and bilc solubility and 6 found to bclong to Group IV and one to Group II. In regard to the mouse inoculation, it is worth noting that the influenza bacillus was frequently obtained from the heart's blood of the mouse after death, and that the pneumococci, although frequently found in the blood or peritoneal cavity of the mouse, never grew in profuse and almost pure culture in the peritoneum, as is usually tlec case when mice arc injected with the sputum from typical lobar pneumonia. 
TABLE VIII.-CULTURES FROM SPUTUM AND NASOPHARYNX.

Thirty-two cases of infuenza without pneumonia from "Transport 56."

\begin{tabular}{|c|c|c|c|c|c|}
\hline \multirow{2}{*}{\multicolumn{2}{|c|}{$\cdot$}} & \multirow{2}{*}{$\begin{array}{l}\text { Sputum. } \\
\text { direct. } \\
\text { culture. }\end{array}$} & \multicolumn{2}{|c|}{$\begin{array}{l}\text { Sputum injected into } \\
\text { motse. }\end{array}$} & \multirow{2}{*}{$\begin{array}{c}\text { Naso- } \\
\text { pharyngeal } \\
\text { swab cultures, }\end{array}$} \\
\hline & & & Peritoncum. & Heart. & \\
\hline 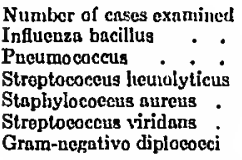 & \begin{tabular}{ll|}
$:$ & $:$ \\
$:$ & $:$ \\
$:$ & $:$ \\
$:$ & $:$ \\
$:$ & $:$
\end{tabular} & $\begin{array}{r}29 \\
22 \\
0 \\
1 \\
7 \\
2 \\
13\end{array}$ & $\begin{array}{r}22 \\
10 \\
10 \\
0 \\
7 \\
2 \\
6\end{array}$ & $\begin{array}{r}22 \\
15 \\
10 \\
0 \\
1 \\
1 \\
4\end{array}$ & $\begin{array}{r}24 \\
10 \\
0 \\
3 \\
1 \\
1 \\
15\end{array}$ \\
\hline
\end{tabular}

These observations were not made until the epidemie in troops from this transport had begun to subside, and it was quite possible that the original infeeting agent might be missed. At this time, however, a number of seeondary eases developed among the hospital personnel and among troops in eontact with the men of this transport at a rest eamp. Forty-eight sputum cultures from sueh eases made by Licut. F. B. Harrington (See Table IX) showed the presence of the influenza baeillus in 32 ; and in 23 of the eases it was found practically in pure eulture, being mixed with only $n$ few colonies of the organisms ordinarily found in the upper respiratory tract.

TABLE IX.-SPUTUM CULTURES FROM CAMP HOSPITAL NO. 35, OCTOBER 10 TO OCTOBER 31.

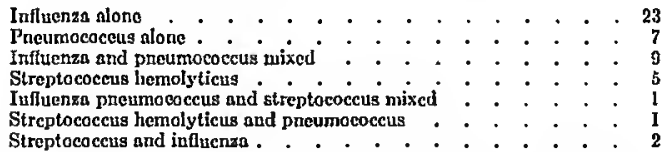

At Base Hospital 29, 70 sputum examinations were made -39 by mouse inoeulation and 31 by the Avery tube. The results were:

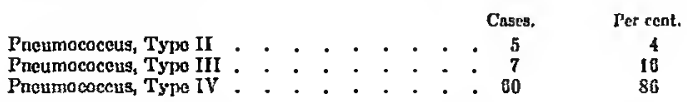

The intluenza bacillus was not recovered. Of sputa from 7 eases of advaneed pneumonia at Ameriean Red Cross M. Hospital 4, 2 showed pneumoeocei alone; 4 pneumococeus and $B$. influenzæ; and 1 pneumoeoeeus and streptococeus. 
Summary. 1. Hipidemiological. elinical and pathologieal observations of the epidemie of influenza as seen in Ameriean troops in England are presented.

2. From the epidemiological findings it appenrs that we are denling with a highly eontagious acute respiratory traet disease. It further appears that the mortality is about twice as high on board transports as on shore-namely 4 per thousand per month at sea and 2 per thousand per month on shore.

3. The most efieetive measures found for controlling the outbreak and for diminishing the mortality bave been found to be $(a)$ prompt isolation of all men showing temperatures and $(b)$ increasing the amount of space allotted to a man. No conclusive evidence is at hand that masking and prophylactic spraying are effectivc, but the authors believe that thesc measures may properly be enrried out, but are not to be solely relied upo:

4. In the matter of hospitalization it appears pretty definitcly thut it is lighly important that eases be moved as little as possible and that they be got to bed with a minimum of delay. Long journeys in hospital trains arc distinctly inadvisable.

5. In regard to the ligher mortality secn at sea it is probable that various debilitating circumstances, such as umpalatable and henee insufficient food, brolien and insufficient sleep), poor ventilation, overeroweling ancl exposure to cold and wet, all may have served to lower the individual resistance to the discase. But it is probable that the high mortality was determined not so mueh by these factors as by the virulence of the infecting organisms. It inust be borne in mind that the troops were all newly reeruitcl and that they left cantonments where a highly viruleut organism was prevalent.

6. Clinically, it scems probablc that the origiual infection is an entity. That when useomplicated the mortality is nearly zero, but that bronehopuenmonia frequently develops and is responsible for practieally all the deaths. Tlie type of bronehopneumonia is unusual. It may be exeeedingly fulmuating and almost explosive in extension, or it may be subacute, rumning a eonrse of ten days to two weeks. It is usually assoeiated witl a purnlent bronehitis. The cause of deatl in the fulminating eases nay be sufioention, in the less rapir ones toxemia. 'The peeuliar features of the pnenmonia are the deep eyanosis, with no canse obvious in the circulation, the absence of pain and orthopnca, the frequent epistaxis, the purulent and bloodstreaked sputum and the lenkopenia.

7. No curative measures of value have been found. In the pnenmonia, oxygen administered may or may jot alter the eyanosis, but in any event does not seem to alter the eourse of the disease. Treatment in general must necessarily be evtirely symptomatie. Veneseetion and saline infusion have not shom any benefieial effeet. Digitalis las been used extensively, but in tle majority of eases there is no elear-cut evidence of earliae ineompetenee. 
8. As to etiology it is impossible, from the reported findings, to draw definite eonelusions as to the primary infecting organism. 'The streptoeoceus, pneumoeocens, staplyyloeoeeus and meningoeoeeus were found so irregularly that we believe they ean be exeluded as seeondary invaders. The influenza baeillus was found postmortem frequently, but by no means eonstantly. However, it was found more frequently in the early part of the epidennie than in the Iate, and in the early cases it was often the only organism in the eonsolidated lung. It was found more frequently in the freslily eonsolidated lung than in older lesions. It was also found witls eonsiderable regularity in the sputum and nasoplarynx of grip eases uncomplieated by pneumonia. These faets seemed to indieate that the Pfeifier baeillus was the primary cause of the epidemie, though the evidenee is not eonelusive. The observations of Charles Nicolle at Tunis of the presenee of a filterable virus offer an alternative explanation. In eonelusion, we ean only state that this epidemie was due to infeetion by either the baeillus of Pfeiffer or by some mieroörganism not recoverable by the methods employed.

\section{THE ONIDENTIFIED PANDEMTC DISEASE (INFLDENZA?),}

\section{Br Dudetr Roberts, M.D., Major, M.C., U.S.A., NEw Yolk.}

T'ue pandemie of acute respiratory disease whieh started in Europe in 1018 is still unidentified. Clinieally and pathologieally it is a new disease, differing widely from familinr maladies and epidemics within our experience or described in the literature of medieine. The etiology, in fact, of epidemics which lave eome down through history as "influeuza" is fully as uneertain as the present one, during which tlie opportunities for aceurate laboratory study lave been unpreeedented. The ultimate solution of this problem must rest with tlie baeteriologist.

The disease is still epidemie in many quarters and the persistenee of seattered eases when the epidemic first appeared makes it extremely probable that it will be added to the eategory of eudemie eontagious diseases. The prompt recognition of isolated eases is exeeelingly important for the individual and the eommunity. An opportunity for the study of the disease has been offered in our military liospitals, which is not liable to be dmplieated.

The elinieal material ou which this comnunieation is based eomprises about 1500 eases numder observation from the begiming of the epidemie until the middle of December at U. S. Army General Iospital No. 1 (Colmmbia War Hospital), Williamsbridge, N. Y.; 